\title{
IMPLEMENTASI MODEL PEMBELAJARAN BERBASIS PROYEK PENDEKATAN SETS TERHADAP KEMAMPUAN BERPIKIR KREATIF PESERTA DIDIK
}

\author{
Ummu Kalsum ${ }^{1, \mathrm{a}}$, Hardi Hamzah ${ }^{2, \mathrm{~b}}$, Nasriani $\mathrm{M}^{3, \mathrm{c}}$ \\ ${ }^{1,2,3}$ Program Studi Pendidikan Fisika, Fakultas Kuguruan dan Ilmu Pendidikan, \\ Universitas Sulawesi Barat. \\ e-mail: ummu.kalsum@unsulbar.ac.id, hhardi@unsulbar.ac.id, ${ }^{c}$ nasriani@unsulbar.ac.id
}

\begin{abstract}
Abstrak
Penelitian ini bertujuan untuk mengetahui kemampuan berpikir kreatif peserta didik yang menerapkan model pembelajaran berbasis proyek dengan pendekatan SETS, kemampuan berpikir kreatif peserta didik yang menerapkan pembelajaran konvensional, dan perbedaan yang signifikan kemampuan berpikir kreatif peserta didik antara kedua kelas. Metode yang digunakan dalam penelitian ini adalah quasi-eksperimen dengan desain non-equivalent control group design. Populasi dalam penelitian ini adalah seluruh peserta didik kelas X SMA Negeri 1 Majene. Sampel yang diteliti sebanyak 76 orang terdiri dari 38 peserta didik sebagai kelas eksperimen dan 38 peserta didik sebagai kelas kontrol yang dipilih dengan teknik sampling purposive. Instrumen pengumpulan data berbentuk tes uraian. Data dianalisis dengan menggunakan analisis deskriptif dan inferensial. Penelitian menunjukkan bahwa kemampuan berpikir kreatif peserta didik kelas eksperimen berada pada kategori cukup kreatif (skor rata-rata sebesar 19.79), kemampuan berpikir kreatif peserta didik pada kelas kontrol berada pada kategori tidak kreatif (skor rata-rata sebesar 15.18) dan terdapat perbedaan yang signifikan antara kedua kelas $\left(\mathrm{t}_{\text {hitung }}=6.8778>\mathrm{t}_{\text {tabel }}=1.993\right)$ pada taraf signifikansi $5 \%$.
\end{abstract}

Kata kunci: Model Pembelajaran Berbasis Proyek, Pendekatan SETS, Kemampuan Berpikir Kreatif

\section{IMPLEMENTATION OF THE SETS APPROACH PROJECT-BASED LEARNING MODEL ON STUDENTS' CREATIVE THINKING ABILITY}

\begin{abstract}
This study aimed to find out the student's creative thinking abilities applying the project-based learning model with the SETS approach, the creative thinking abilities of students implementing conventional learning, and significant differences in student's creative thinking abilities between the two classes. The research was quasiexperimental design with non-equivalent control group design. The population were tenth grade of SMA Negeri 1 Majene. The studied sample were 76 students consisting of 38 students as the experimental class and 38 students as the control class chosen by purposive sampling. Data was collected by essay test. The data was analyzed with descriptive and inferential statistics. The research result proved that the creative thinking abilities ware creative enough (average score of 19.78) in treatment class, not creative (average score of 15.18) in control class, and there was a significantly differences between two classes $\left(t_{\text {count }}=6,8778>t_{\text {table }}=1,9993\right)$ at the 5\% significance level.
\end{abstract}

Keywords: Project-Based Learning Model, SETS Approach, Creative Thinking Ability

\section{PENDAHULUAN}

Dewasa ini persaingan semakin ketat, jika tidak memiliki kemampuan untuk bersaing maka kita akan tersisihkan dan tidak mampu bertahan hidup. Ketatnya persaingan ini telah mempengaruhi semua aspek kehidupan termasuk di dunia Pendidikan. Oleh karena itu, diperlukan adanya Sumber Daya Manusia (SDM) yang mampu berpikir kreatif dalam mengikuti perkembangan tersebut.

Kemampuan berpikir kreatif dipandang penting karena dapat mewujudkan pribadi yang dapat menyelesaikan suatu masalah dengan melihat berbagai kemungkinan untuk menyelesaikan masalah tersebut, dan juga menjadi bekal untuk peserta didik agar dapat bersaing 
dalam dunia kerja dan dalam kehidupan seharihari. Selain itu, kemampuan berpikir kreatif peserta didik dalam pembelajaran fisika perlu mendapatkan perhatian karena merupakan salah satu aspek dalam tujuan pendidikan [1].

Pada umumnya dalam pembelajaran fisika peserta didik kurang mempunyai kemampuan untuk berpikir kreatif dalam menyelesaikan suatu masalah atau menjawab soal yang diberikan. Hal ini disebabkan karena kemampuan berpikir kreatif peserta didik jarang terlatih. Kenyataan ini diperkuat dari hasil observasi lebih lanjut yang dilakukan dengan memberikan tes kemampuan berpikir kreatif pada mata pelajaran fisika. Bentuk tes yang diujikan berupa tes uraian yang terdiri dari 7 item soal. Hasil tes menunjukkan bahwa secara keseluruhan peserta didik kelas X MIPA SMA Negeri 1 Majene belum mampu memberikan jawaban selain yang terdapat dalam buku atau yang pernah diajarkan oleh guru mata pelajaran. Tentunya hal ini mengindikasikan bahwa kemampuan berpikir kreatif peserta didik pada mata pelajaran fisika masih rendah.

Oleh karena itu, untuk mengatasi permasalahan tersebut guru atau pendidik perlu memilih atau menerapkan suatu model pembelajaran yang dapat melatih kemampuan berpikir kreatif peserta didik. Dalam merangsang kemampuan berpikir kreatif peserta didik, kegiatan pembelajaran harus membawa peserta didik dalam menjawab permasalahan dengan banyak cara dan kemungkinan jawaban yang benar sehingga dapat mengundang potensi intelektual serta kreativitas peserta didik dalam menemukan sesuatu yang baru. Model pembelajaran yang dimaksudkan yaitu model pembelajaran berbasis proyek $(\mathrm{PjBL})$. Model pembelajaran berbasis proyek merupakan pembelajaran yang melibatkan peserta didik dalam transfer pengetahuan dan keterampilan melalui proses penemuan dengan serangkaian pertanyaan dalam tugas atau proyek [2].

Pembelajaran berbasis proyek juga
merupakan salah satu wahana yang
memaksimalkan aktivitas peserta didik dalam
pembelajaran, dapat meningkatkan motivasi dan
kinerja ilmiah peserta didik, dan membantu
mengembangkan keterampilan belajar jangka

panjang [3]. Langkah -langkah pembelajaran berbasis proyek adalah 1) perencanaan proyek, 2) mendesain proyek, 3) menyusun jadwal, 4) monitoring kegiatan dan perkembangan proyek 5) menguji hasil, 6) monitoring dan evaluasi [4].

Dalam pembelajaran yang dilakukan peneliti memadukan dengan pendekatan SETS (Science, Environment, Technology, and society). Pendekatan SETS merupakan salah satu pendekatan yang berpusat pada peserta didik sehingga membuat peserta didik terlatih berpikir secara global, memecahkan masalah dengan menerapkan konsep-konsep yang dimiliki [5].

Pendekatan ini bertujuan memberi pembelajaran sains secara kontekstual, peserta didik dibawa ke situasi untuk memanfaatkan konsep sains ke bentuk teknologi untuk kepentingan masyarakat, diminta untuk berpikir tentang berbagai kemungkinan akibat yang terjadi dalam proses transfer sains tersebut ke teknologi. Ciri pembelajaran SETS yaitu konsep sains yang dibelajarkan tidak sekedar diperkenalkan sebagai konsep sains murni akan tetapi dikaitkan dengan unsur lain dari SETS [6].

Permasalahan dalam penelitian ini meneliti seberapa besar kemampuan berpikir kreatif peserta didik setelah diajar menggunakan model pembelajaran berbasis proyek dengan pendekatan SETS dan kelas yang diajar dengan pembelajaran konvensional dan apakah terdapat perbedaan yang signifikan antara kedua kelas. Tujuan penelitian ini adalah untuk mengetahui seberapa besar kemampuan berpikir kreatif peserta didik pada kelas eksperimen dan kelas kontrol serta untuk mengetahui apakah terdapat perbedaan kemampuan berpikir kreatif peserta didik pada kedua kelas. Manfaat dari penelitian ini adalah dapat dijadikan sebagai bahan kajian bersama agar dapat meningkatkan kualitas pembelajaran di sekolah.

\section{METODE}

Jenis Penelitian ini adalah penelitian QuasiEksperimen dengan desain nonequivalent control group [7]

$\begin{array}{lll}\mathbf{O}_{1} & \mathbf{X} & \mathrm{O}_{2} \\ \mathbf{O}_{3} & & \mathbf{O}_{4}\end{array}$


Penelitian ini dilaksanakan di SMA Negeri 1 Majene, pada semester genap tahun ajaran 2018/2019.

Populasi dalam penelitian ini adalah seluruh peserta didik kelas X MIPA SMA Negeri 1 Majene tahun ajaran 2018/2019 dengan sampel penelitian kelas X MIPA 2 sebagai kelas eksperimen dan kelas X MIPA 4 sebagai kelas kontrol. Pemilihan sampel ini menggunakan teknik sampling purposive. Adapun prosedur pengumpulan data dalam penelitian terdiri dari 3 tahap yaitu pertama adalah tahap persiapan. Pada tahap ini peneliti melaksanakan observasi ke sekolah, konsultasi dengan guru serta kepala sekolah untuk mengurus surat perizinan, menentukan sampel yang akan menjadi objek penelitian, memilih pokok bahasan yang akan dijadikan sebagai materi dalam penelitian, menyusun instrumen tes berpikir kreatif dan kisi-kisi instrumen yang akan digunakan dalam penelitian, menyusun Rencana Pelaksanaan Pembelajaran (RPP) sesuai dengan materi yang diajarkan, dan melakukan melakukan validasi item terhadap instrumen yang dibuat.

Tahap kedua adalah tahap rencana pelaksanaan yaitu sebelum perlakuan Memberikan penjelasan secara singkat dan menyeluruh terhadap peserta didik kelas X MIPA SMA Negeri 1 Majene sehubungan dengan materi yang diajarkan kemudian memberikan tes awal dengan menggunakan instrumen tes (Pretest) untuk mengetahui kemampuan berpikir kreatif peserta didik sebelum model pembelajaran diterapkan. Selanjutnya adalah perlakuan memberikan perlakuan dengan menggunakan model pembelajaran berbasis proyek yang berorientasi pada pendekatan SETS untuk kelas eksperimen dan pembelajaran konvensional untuk kelas kontrol setelah diberikan perlakuan peserta didik kembali diberikan tes akhir dengan menggunakan instrumen tes yang diberikan pada tes awal.

Kemudian tahap akhir dalam penelitian ini adalah mengolah data hasil penelitian dengan menggunakan teknik analisis data yang sesuai. Data yang diperoleh dalam penelitian ini berupa data kemampuan berpikir kreatif peserta didik kedua kelas. Data kemampuan berpikir kreatif peserta didik diperoleh dari hasil pretest dan posttest berupa soal- soal berbentuk tes uraian (essay) yang terdiri dari 7 item soal.

Teknik analisis data yang digunakan dalam penelitian ini adalah analisis deskriptif dan analisis inferensial. Teknik analisis deskriptif digunakan untuk mendeskripsikan data penilaian model pembelajaran dan kemampuan berpikir kreatif peserta didik. Rumus yang digunakan dalam analisis deskriptif untuk penelitian ini adalah:

Skor Rata-Rata $(\bar{X})[8]$

$\bar{X}=\frac{\sum x_{i}}{n}$

Standar Deviasi [9]

$S=\sqrt{\frac{\sum\left(X_{i}-\bar{X}\right)^{2}}{n-1}}$

Untuk mengetahui nilai yang diperoleh peserta didik, maka skor diubah ke nilai dengan rumus sebagai berikut [10]:

Nilai $=\frac{\text { skor mentah }}{\text { skor maksimum ideal }} \times 100$

Adapun kriteria nilai kemampuan berpikir kreatif dapat dilihat pada tabel berikut [11]:

Tabel 1. Taraf Ketercapaian Kemampuan Berpikir Kreatif Peserta Didik

\begin{tabular}{cc}
\hline Keberhasilan Tindakan & Kriteria \\
\hline $95 \leq \mathrm{PK} \leq 100$ & Sangat Kreatif \\
$80 \leq \mathrm{PK}<95$ & Kreatif \\
$65 \leq \mathrm{PK}<80$ & Cukup Kreatif \\
$55 \leq \mathrm{PK}<65$ & Kurang Kreatif \\
$\mathrm{PK}<55$ & Tidak kreatif \\
\hline
\end{tabular}

Selanjutnya teknik analisis inferensial digunakan untuk membuktikan hipotesis yang diajukan dengan menggunakan uji-t. namun sebelum dilakukan pengujian dengan uji-t terlebih dahulu dilakukan pengujian prasyarat diantaranya adalah pengujian normalitas. Uji normalitas data yang digunakan dalam penelitian adalah uji Chikuadrat dengan rumus sebagai berikut [8]: 
$\chi^{2}=\frac{\sum\left(O_{i}-E_{i}\right)^{2}}{E_{i}}$

Kriteria pengujian pada taraf signifikan $\alpha=$ 0,05 yaitu jika $\chi^{2}$ hitung $<\chi^{2}$ tabel, maka data berdistribusi normal. Jika $\chi^{2}$ hitung $\geq \chi^{2}$ tabel, maka data berdistribusi tidak normal.

Selanjutnya dilakukan pengujian homogenitas untuk mengetahui homogenitas kedua data. Uji homogenitas pada penelitian ini menggunakan rumus sebagai berikut [8]:

$F=\frac{s_{1}^{2}}{s_{2}{ }^{2}}$

Pengujian hipotesis pada penelitian ini menggunakan uji - t, dengan taraf nyata $\alpha=0,05$ [12]:

$\mathrm{t}_{\text {hitung }}=\frac{\bar{x}_{1}-\bar{x}_{2}}{\sqrt{\frac{s_{1}^{2}}{n_{1}}+\frac{s_{2}^{2}}{n_{2}}}}$

Nilai $t_{\text {tabel }}$ dicari pada tabel distribusi- $\mathrm{t}$ dengan ketentuan: $\mathrm{dk}=n_{1}+n_{2}-2$, sehingga $t_{\text {tabel }(\alpha, d k)}[9]$ :

Dengan kriteria pengujian untuk $t$ adalah:

$t_{\text {hitung }} \geq t_{\text {tabel }}$ maka $\mathrm{H}_{a}$ diterima,

$t_{\text {hitung }}<t_{\text {tabel }}$ maka $\mathrm{H}_{a}$ ditolak dan $\mathrm{H}_{0}$ diterima

\section{HASIL DAN DISKUSI}

Berdasarkan hasil analisis diperoleh data kemampuan berpikir kreatif sebagai berikut:

Tabel 2. Kemampuan Berpikir Kreatif

\begin{tabular}{ccccc}
\hline \multirow{2}{*}{$\begin{array}{c}\text { Kompone } \\
\text { n }\end{array}$} & \multicolumn{2}{c}{ Pretest } & \multicolumn{2}{c}{ Posttest } \\
\cline { 2 - 5 } & $\begin{array}{c}\text { eksperi } \\
\text { men }\end{array}$ & $\begin{array}{c}\text { kontr } \\
\text { ol }\end{array}$ & $\begin{array}{c}\text { eksper } \\
\text { imen }\end{array}$ & $\begin{array}{c}\text { kontr } \\
\text { ol }\end{array}$ \\
\hline $\begin{array}{c}\text { Skor } \\
\text { tertinggi } \\
\text { Skor }\end{array}$ & 19 & 13 & 25 & 20 \\
terendah & 5 & 5 & 19 & 9 \\
Rata-rata & 9,11 & 5,85 & 19,79 & 15,18 \\
\hline
\end{tabular}

Berdasarkan tabel di atas terlihat kemampuan berpikir kreatif peserta didik pada kedua kelas mengalami perubahan skor yaitu berupa peningkatan skor rata-rata sebelum dan setelah diberi perlakuan. Dimana sebelum diberi perlakuan kedua kelas berada pada kategori tidak kreatif hal ini dapat dilihat dari perolehan skor ratarata kedua kelas yaitu pada kelas eksperimen sebesar 9,11 atau setara dengan nilai 31,81 dan kelas kontrol sebesar 8,58 atau setara dengan nilai 29,68 .

Setelah diberikan perlakuan pada kedua kelas diperoleh hasil skor rata-rata untuk kelas eksperimen sebesar 19, 79 atau setara dengan nilai 67,08 dan berada pada kategori cukup kreatif hal ini menandakan bahwa pada kelas eksperimen yaitu kelas yang menerapkan model pembelajaran berbasis proyek dengan pendekatan SETS dapat melatih kemampuan berpikir kreatif peserta didik. Sedangkan pada kelas kontrol terlihat skor rata-rata yang diperoleh sebesar 15,18 atau setara dengan nilai 53,89 dan berada pada kategori tidak kreatif. Hal ini menunjukkan bahwa pada kelas kontrol kemampuan berpikir kreatifnya kurang terlatih.

Lebih jelasnya hasil kemampuan berpikir kreatif peserta didik disajikan pada tabel 3.

Tabel 3. Hasil kemampuan berpikir kreatif peserta didik

\begin{tabular}{cccc}
\hline Objek & \multirow{2}{*}{ kategori } & \multicolumn{2}{c}{ Jumlah siswa } \\
\cline { 3 - 4 } penelitian & pretest & posttest \\
\hline \multirow{5}{*}{ eksperimen } & kreatif & - & 2 \\
& $\begin{array}{c}\text { Cukup } \\
\text { kreatif }\end{array}$ & - & 19 \\
& $\begin{array}{c}\text { Kurang } \\
\text { kreatif }\end{array}$ & - & 14 \\
& $\begin{array}{c}\text { Tidak } \\
\text { kreatif } \\
\text { kreatif }\end{array}$ & 38 & 3 \\
kontrol & $\begin{array}{c}\text { Cukup } \\
\text { kreatif }\end{array}$ & - & - \\
& $\begin{array}{c}\text { Kurang } \\
\text { kreatif }\end{array}$ & - & 14 \\
& $\begin{array}{c}\text { Tidak } \\
\text { kreatif }\end{array}$ & 38 & 21 \\
\hline
\end{tabular}

Hasil rekapitulasi persentase indikator kemampuan berpikir kreatif kelas eksperimen melalui metode tes meliputi berpikir lancar $74,25 \%$, berpikir luwe $75 \%$, berpikir orisinal $46,75 \%$, dan kemampuan elaborasi $48 \%$.sedangkan pada kelas kontrol meliputi berpikir lancar 54\%, berpikir luwes $65,75 \%$, 
berpikir orisinal 33,5\% dan kemampuan elaborasi $36,75 \%$.

Berdasarkan analisis data, rata-rata kemampuan berpikir kreatif peserta didik mengalami peningkatan baik pada kelas eksperimen maupun pada kelas kontrol. Akan tetapi peningkatan kelas eksperimen lebih tinggi daripada kelas kontrol. Hal ini disebabkan karena dalam pembelajaran kelas eksperimen menggunakan model pembelajaran berbasis proyek dengan pendekatan SETS dapat melatih sisi kreatif peserta didik dimana setiap fase dalam pembelajaran berbasis proyek melibatkan peserta didik secara aktif, bahkan sebagian besar kegiatan berada pada peserta didik. Hal inilah yang memberikan peluang peningkatan nilai posttest peserta didik.

Sejalan dengan hasil penelitian yang menyatakan bahwa pembelajaran berbasis proyek dapat meningkatkan aspek kemampuan berpikir kreatif peserta didik [2]. Penelitian lainnya juga menunjukkan bahwa hasil yang diperoleh terdapat peningkatan kemampuan berpikir kreatif yang signifikan setelah diterapkan model pembelajaran berbasis proyek [12].

Penelitian yang dilakukan oleh Adista Candra Yusro (2015) mengenai perangkat pembelajaran fisika bervisi SETS untuk meningkatkan kemampuan berpikir kreatif siswa. Hasil yang diperoleh menyimpulkan bahwa terdapat perbedaan kemampuan berpikir kreatif siswa antara sebelum dan sesudah pelaksanaan pembelajaran.

Sedangkan kelas kontrol dalam pembelajarannya menggunakan pembelajaran konvensional, dimana pembelajaran masih berpusat pada guru proses belajar dalam kelas peserta didik kurang aktif, interaksi antara peserta didik kurang, tidak ada diskusi kelas sehingga kurang melatih kemampuan berpikir kreatif peserta didik.

Berdasarkan Hasil pengujian normalitas data skor kemampuan berpikir kreatif peserta didik sebelum dan setelah diberikan perlakuan udapat dilihat pada tabel berikut:
Tabel 4. Hasil Uji Normalitas

\begin{tabular}{ccc}
\hline \multirow{2}{*}{ kelas } & \multicolumn{2}{c}{$\chi^{2}{ }_{\text {hitung }}<\chi^{2}{ }_{\text {tabel, }}$} \\
\cline { 2 - 3 } & Pretest & posttest \\
\hline \multirow{2}{*}{ eksperimen } & $2,61<$ & $2,17<$ \\
& 11,0701 & 11,0701 \\
\hline \multirow{2}{*}{ kontrol } & $0,70<$ & $6,71<$ \\
& 11,0701 & 11,0701 \\
\hline
\end{tabular}

Tabel 4 menunjukkan bahwa data kemampuan berpikir kreatif peserta didik kedua kelas berdistribusi normal.

Data yang berdistribusi normal selanjutnya diuji homogenitas untuk menguji apakah kedua data yang dibandingkan memiliki varians yang homogen atau tidak. Berdasarkan hasil perhitungan diperoleh nilai sig. 0,864. Hal ini mengindikasikan bahwa data pada pretest untuk kedua kelas memiliki varians yang homogen. Selanjutnya pada posttest diperoleh nilai sig. 0,678 yang juga berarti data kemampuan berpikir kreatif untuk kedua kelas memiliki varians yang homogen.

Selanjutnya data pengujian hipotesis dengan menggunakan uji-t pada taraf signifikan 5\% diperoleh harga $t_{\text {hitung }}=6,8778$ dan harga $t_{\text {tabel }} 1,993$ yang berarti $t_{\text {hitung }}>t_{\text {tabel }}$ sehingga hasil pengujian hipotesis berada pada penolakan $\mathrm{H}_{0}$ dan penerimaan $\mathrm{H}_{\mathrm{a}}$. Dengan demikian, dapat disimpulkan bahwa terdapat perbedaan signifikan antara kemampuan berpikir kreatif peserta didik pada kedua kelas.

\section{SIMPULAN DAN SARAN Simpulan}

Berdasarkan analisis, disimpulkan bahwa pada kelas eksperimen setelah diterapkan model pembelajaran berbasis proyek dengan pendekatan SETS kemampuan berpikir kreatif peserta didik berada pada kategori cukup kreatif sedangkan pada kelas kontrol yaitu dengan pembelajaran konvensional kemampuan berpikir kreatif peserta didik berada pada kategori tidak kreatif, dan terdapat perbedaan yang signifikan terhadap kemampuan berpikir kreatif peserta didik antara kelas yang diajar menggunakan model pembelajaran berbasis proyek dengan pendekatan SETS dan kelas yang diajar menggunakan 
pembelajaran konvensional dengan taraf signifikansi 0,05 .

\section{Saran}

Beberapa saran yang dapat diberikan peneliti setelah melaksanakan pembelajaran dengan menerapkan model pembelajaran berbasis proyek dengan pendekatan SETS yaitu dalam melaksanakan pembelajaran dengan menerapkan pembelajaran berbasis proyek dengan pendekatan SETS dibutuhkan waktu yang cukup lama, sehingga guru harus dapat mengelola waktu sesuai dengan perencanaan. Sebaiknya untuk penelitian selanjutnya dapat melatih sisi kreatif peserta didik dengan memberikan tugas mandiri seperti PR berupa permasalahan yang mempunyai lebih dari satu solusi. Untuk penelitian selanjutnya diharapkan peneliti terlebih dahulu melakukan observasi awal secara rinci mengenai waktu belajar peserta didik dan kegiatan-kegiatan yang ada di sekolah yang mungkin dapat mengganggu penelitian. Ada baiknya peserta didik ditugaskan untuk mempelajari materi yang akan dipelajari pada pertemuan berikutnya agar dalam waktu yang digunakan untuk membuat rancangan proyek di kelas bisa lancar. Perlunya penelitian lebih lanjut pada materi, kelas dan sekolah yang berbeda.

\section{DAFTAR PUSTAKA}

[1] Priantinidewa dkk, Pengaruh Metode Mind Mapping Terhadap Keterampilan Berpikir Kreatif dan Prestasi Belajar IPS. e-journal Program Pasca sarjana Universitas Pendidikan Ganesha. Vol.3.2013.

[2] Luthvitasari, Navies, Ngurah Made D.P, Suharto Linuwih.Implementasi Pembelajaran Fisika Berbasis Proyek Terhadap Keterampilan Berpikir Kritis, Berpikir Kreatif Dan Kemahiran Generic Sains. Semarang. Jurnal of Innovative Science Education.2012.

[3] Fathurrohman, Muhammad. Model Model Pembelajaran Inovatif. Jokjakarta: Ar-Ruzz Media; 2015.

[4] Kementrian Pendidikan dan Kebudayaan 2013. Model Pembelajaran Berbasis Proyek (Project Based Learning).

[5] Rini, Candra Puspita.2017. Pengaruh

[6] Pendekatan SETS (Science, Environment, Technology and Society) Terhadap
Keterampilan Proses Sains. Tangerang. JurnalIlmiahPendidikanDasar Vol. 1 ISSN:2477-2143

[7] Yusro, Adista Candra. Pengembangan Perangkat Pembelajaran Fisika Berbasis SETS Untuk Meningkatkan Kemampuan Berpikir Kreatif Siswa Madium. JPFK,Vol.1 No 2. 2015.

[8] Badan Pengembangan Sumber Daya Manusia Pendidikan Dan Kebudayaan Dan Penjaminan Mutu Pendidikan Kementrian Pendidikan Kebudayaan 2014. Materi Pelatihan Implentasi Kurikulum 20132014 Mata PelajaranFisika SMA/SMK. Siregar, Syofian. Statistik Parametrik Untuk Penelitian Kuantitatif. Jakarta: Bumi Aksara; 2017.

[9] Susetyo,Budi. Statistika Untuk Analisis Data Penelitian. Bandung: PT Refika Aditama. 2017. Susetyo,Budi. Statistika Untuk Analisis Data Penelitian. Bandung: PT Refika Aditama; 2014.

[10] Majid, Abdul. Startegi pembelajaran: PT. Remaja Rosda Karya: 2016.

[11] Firdaus, dkk. Meningkatkan Berpikir Kreatif Matematis Siswa SMA Melalui Pembelajaran Open-Ended Pada Materi SLPDV. Jurnal pendidikan.2016.

[12] Sugiyono. Metode Penelitian Pendidikan Bandung: Alfabeta.2015. 